\title{
PENERAPAN METODE PERAMALAN RUNTUT WAKTU DALAM MENENTUKAN TARGET TINGKAT HUNI KAMAR DI HOTEL EL CAVANA BANDUNG
}

\author{
Zulkifli Harahap \\ Sekolah Tinggi Pariwisata Bandung \\ zharahap73@yahoo.com
}

\begin{abstract}
ABSTRAK
Sebagai sebuah bentuk usaha komersil, tentunya hotel berusaha mendapatkan pendapatan yang sebesar-besarnya. Pada usaha akomodasi seperti hotel, pendapatan yang diterima umumnya berasal dari 3 departemen, yaitu:

Rooms Department, Food and Beverage Department, dan Minor Operating Department, seperti: Telephone, Business Centre, Leisure Activities, Spa dan lain sebagainya. Kamar sebagai core product dari sebuah hotel dimana dalam menentukan besar kecilnya tingkat pendapatan yang diterima dari Room Department, dapat dilihat dari pendekatan Occupancy Rate, Average Room Rate, serta REVPAR (Revenue per Available Room). Pada setiap hotel secara umumnya, Rooms Department menyumbang pendapatan yang sedemikian besar bagi pendapatan hotel secara keseluruhan.

Demikian juga khususnya bagi pihak manajemen Hotel EL Cavana Bandung. Dalam mengukur pendapatan tersebut, terlebih dahulu kita dapat melihat melalui seberapa besar jumlah kamar yang terjual dalam suatu periode waktu tertentu. Untuk mencermati keberhasilan penerapan forecast yang telah dibuat sebelumnya terhadap besar aktual yang dicapai, sederhananya kita dapat melihat sejauh mana besar perbedaan dari masing-masing variabel tersebut, atau yang biasa disebut varian (variance).

Dari hasil penelitian dapat disimpulkan bahwa; penerapan metode peramalan runtut waktu (time series) menghasilkan hasil yang lebih baik dibandingkan dengan penetapan target oleh pihak manajemen Hotel EL Cavana Bandung sebelumnya, dan dimana pada akhirnya kesimpulan utama yang dapat penulis utarakan adalah: penerapan metode Exponential Smoothing dengan $\alpha=0,7$ dinilai sebagai metode peramalan yang paling tepat dalam menentukan target tingkat huni kamar di Hotel EL Cavana Bandung pada semester II tahun 2015.
\end{abstract}

Kata kunci: Tingkat hunian, rata-rata harga kamar, serta REVPAR (pendapatan dari setiap kamar yang tersedia), runtut waktu, proyeksi, varian. 


\title{
THE IMPLEMENTATION OF FORECASTING METHOD FOR DETERMINING LEVEL OF TARGET ROOMS IN EL CAVANA HOTEL BANDUNG
}

\begin{abstract}
As a form of commercial enterprise, of course, the hotel is trying to get the maximum revenue. In accommodation services such as hotels, earned income generally comes from three departments, namely: Rooms Department, Food and Beverage Department, and Minor Operating Department, such as: Telephone, Business Centre, Leisure Activities, Spa and others. Room as a core product of a hotel in which to determine the size of the level of income received from Room Department, can be seen from the approach Occupancy Rate, Average Room Rate and RevPAR (Revenue per Available Room). At each hotel in general, Rooms Department accounted for such a large revenue for the overall hotel revenues. Similarly, in particular for the management of EL Cavana Hotel Bandung.

In measuring these returns, we must first be able to see through how big the number of rooms sold in a given time period. To examine the successful implementation of the forecast that has been made before the actual big achieved, simply we can see the extent of the differences of each of these variables, or socalled variance (variance). From the results of this study concluded that; application of methods of forecasting time series (time series) produce better results than the setting of targets by management Hotel Bandung EL Cavana before, and where in the end the main conclusions that can be uttered authors are: application of methods Exponential Smoothing with $\alpha=0.7$ rated as the most appropriate forecasting method in determining the target level of habitable rooms in Hotel EL Cavana Bandung in the second semester 2015.
\end{abstract}

Keywords: Occupancy rate, Average room, and REVPAR (revenue per available room), Time series, Forecast, Variance.

\section{PENDAHULUAN}

Pariwisata merupakan salah satu industri yang berperan dalam menyumbangkan devisa bagi negara dan terus dikembangkan serta direncanakan sebagai suatu fondasi bagi pembangunan Indonesia dan telah menjadi andalan selain sektor minyak bumi dan gas. Potensi sumber daya pariwisata yang terdapat di Indonesia seperti keindahan alam, iklim tropis, budaya, dan sejarah adalah daya tarik tersendiri bagi para wisatawan baik domestik maupun mancanegara.

Hotel sebagai salah satu fasilitas penunjang kegiatan wisata, dan sarana untuk memenuhi kebutuhan akomodasi pada umumnya, seperti yang dinyatakan oleh Sulastiyono (2004:5) bahwa: - Hotel adalah suatu perusahaan yang dikelola oleh pemiliknya dengan menyediakan pelayanan makanan dan minuman dan fasilitas kamar untuk tidur kepada orang-orang yang sedang melakukan perjalanan 
dan mampu membayar dengan jumlah yang khusus sesuai dengan yang diterima tanpa adanya perjanjian khusus". Usaha-usaha akomodasi seperti hotel dan sejenisnya pun meningkat, baik dari segi kuantitas maupun segi kualitas. Pada tahun 2015 jumlah hotel berbintang di kota Bandung menurut data dari Disbudpar Provinsi Jawa Barat mencapai 154 buah. Besarnya jumlah tersebut mengindikasikan adanya persaingan yang ketat di antara para penyedia sarana akomodasi di kota Bandung dalam menarik tamu.

Intensitas persaingan yang sangat tinggi ini sangat menguji kemampuan sebuah hotel dalam berkompetisi dan mempertahankan kelangsungan usahanya. Oleh karena itu kegiatan manajemen yang baik sebagai alat untuk mencapai tujuan mutlak diperlukan. Konsep perencanaan yang merupakan bagian dari proses manajemen cenderung dikaitkan dengan beberapa bentuk pengambilan keputusan yang melibatkan keadaan masa depan. Drucker yang pernyataannya dikutip oleh Makridakis, Wheelwright dan McGee (2009:209) menguraikan: "Perencanaan sebagai pengenalan secara sadar akan masa depan dari keputusan yang dibuat saat ini." Bagi setiap perusahaan ataupun organisasi termasuk hotel, guna merumuskan strategi serta berbagai pengorganisasian kegiatan yang akan dilakukan bagi setiap untuk masa mendatang, diperlukan sebuah dasar perencanaan yang baik. Menurut Cobbins dan Coulter di dalam Hermaya dan Slamet (2004:174), bahwa: Perencanaan adalah proses yang mencakup mendefinisikan sasaran organisasi, menetapkan strategi menyeluruh untuk mencapai sasaran itu, dan menyusun serangkaian rencana yang menyeluruh untuk mengintegrasikan dan mengkoordinasikan perencanaan organisasi." Hal senada pun dikemukakan oleh Molan (2002:115), menyebutkan bahwa: "Perencanaan (planning) adalah kegiatan menetapkan apa yang harus dilakukan untuk membawa perusahaan dari keadaannya sekarang ke dalam keadaan mendatang. Termasuk disini menentukan sasaran, mengembangkan strategi dan taktik untuk mencapai sasaran tersebut." Untuk itulah dibutuhkan, metode prakiraan atau peramalan (forecasting) sebagai salah satu cara dalam menetapkan target di masa datang agar pihak manajemen dapat menetapkan strategi yang menyeluruh untuk mencapai target tersebut. Sebuah sasaran organisasi akan lebih mudah dicapai apabila, dalam situasi tersebut, orang-orang di dalam organisasi memiliki motivasi dan memahami komitmen terhadap sasaran yang dimaksud.

Demikian perencanaan seperti halnya penerapan target, ataupun peramalan, akan melahirkan sebuah aktivitas operasi yang bernilai efektif dan efisien. Berikut ini adalah pandangan mengenai peramalan menurut Hanke dan Wichern (2005:1), "In view of the inherent inaccuracies in the process, why is forecasting necessary? The answer is that all organizations operate in a atmosphere of uncertainty but decisions must be made today that affect the future of organization. Educated guesses about the future are more valuable to organization managers than uneducated guesses". Dari kutipan diatas, berbagai ketidakpastian akan keadaan di masa mendatang, dapat diminimalisir dengan kemampuan seorang decision maker dalam mengetahui kemampuan memprakirakan masa depan itu sendiri. Makridakis dalam Hanke dan Wichern (2005:2), menyebutkan bahwa: 
Humans possess unique knowledge and inside information not available to quantitative methods. Surprisingly, however, empirical studies and laboratory experiments have shown that their forecasts are not more accurate than those of quantitative methods. Humans tend to be optimistic and underestimate future uncertainty...In addition, the cost of forecasting with judgmental methods is often considerably higher than when quantitative methods are used.

Hal ini tidaklah dimaksudkan bahwa forecasting berdasarkan intuisi itu salah, namun keterbatasan pengetahuan akan keadaan-keadaan di masa datang hanya akan membuat terbatasnya peramalan yang dapat diterapkan. Dengan adanya teknik metode forecasting, pengetahuan ini dapat meningkatkan managerial ability serta common sense khususnya bagi seorang pengambil keputusan dalam mengambil keputusan untuk masa datang. Untuk lebih jelasnya sejauh mana peranan forecasting dapat berguna bagi manajemen, berikut adalah ilustrasi seperti yang dikemukakan oleh Bernstein dalam Hanke dan Wichern (2005:3):

You do not plan to ship goods across the ocean, or to assemble merchandise for sale, or to borrow without first trying to determine what the future may hold in store. Ensuring that the materials you order are delivered on time, seeing to it that the items you plan to sell are produced on schedule, and getting your sales facilities in place all must be planned before that moment when the customers show up and lay their money on the counter. The successful business executive is a forecaster first; purchasing, producing, marketing, pricing, and organizing all follow.

Krajewski, et al (2007:504), menyebutkan bahwa: "Forecast is a prediction of future events for planning purpose". Sedangkan Makridakis (2014:54) menerangkan bahwa: "Peramalan adalah prediksi nilai-nilai sebuah variabel berdasarkan kepada nilai-nilai yang diketahui dari variabel-variabel tersebut atau variabel lainnya yang berhubungan. Peramalan yang dilakukan diharapkan dapat membantu pihak manajemen dari setiap perusahaan dalam pengambilan keputusan berdasar atas berbagai situasi mendatang yang tidak pasti. Tentunya dalam hal ini, pada akhirnya pihak manajemen akan menerima pengaruh kedepannya, baik dari segi internal maupun dari segi eksternal, yang cenderung tidak terkendali. Namun dengan adanya forecasting, seorang pengambil keputusan memiliki bayangan yang cukup dalam membuat perencanaan yang matang untuk mengantisipasi keadaan yang akan datang, sehingga pada akhirnya pengambil keputusan tersebut dapat mengarahkan dan mengkoordinasikan setiap divisi atau departemennya sesuai dengan perencanaan yang telah dibuat sebelumnya.

Sebagai sebuah bentuk usaha komersil, tentunya hotel berusaha mendapatkan pendapatan yang sebesar-besarnya. Pada usaha akomodasi seperti hotel, pendapatan yang diterima umumnya berasal dari 3 departemen, yaitu:

Rooms Department, Food and Beverage Department, dan Minor Operating Department, seperti: Telephone, Business Centre, Leisure Activities, Spa dan lain sebagainya. Kamar sebagai core product dari sebuah hotel dimana dalam 
menentukan besar kecilnya tingkat pendapatan yang diterima dari Room Department, dapat dilihat dari pendekatan Occupancy Rate, Average Room Rate, serta REVPAR (Revenue per Available Room). Pada setiap hotel secara umumnya, Rooms Department menyumbang pendapatan yang sedemikian besar bagi pendapatan hotel secara keseluruhan. Demikian juga khususnya bagi pihak manajemen Hotel EL Cavana Bandung. Dalam mengukur pendapatan tersebut, terlebih dahulu kita dapat melihat melalui seberapa besar jumlah kamar yang terjual dalam suatu periode waktu tertentu. Untuk mencermati keberhasilan penerapan forecast yang telah dibuat sebelumnya terhadap besar aktual yang dicapai, sederhananya kita dapat melihat sejauh mana besar perbedaan dari masing-masing variabel tersebut, atau yang biasa disebut varian (variance).

\section{METODE PENELITIAN}

Menurut tingkat eksplanasi yang ada, maka penelitian yang dilakukan penulis merupakan penelitian kuantitatif deskriptif. Penelitian deskriptif adalah penelitian yang dilakukan untuk mengetahui nilai variabel mandiri, baik satu variabel atau lebih (independen) tanpa membuat perbandingan, atau menghubungkan antara variabel satu dengan variabel yang lain (Sugiyono, 2005:11). Sedangkan penelitian kuantitatif dipilih karena hasil penelitian yang diperoleh berupa data angka yang selanjutnya diolah agar data tersebut memiliki makna.

\section{Objek Penelitian}

Objek dalam penelitian ini adalah pihak manajemen Hotel EL Cavana Bandung yang berkepentingan dalam menetapkan target tingkat huni kamar.

\section{Sumber Data Penelitian}

Sumber data pada penelitian ini adalah laporan tahunan tingkat hunian kamar Hotel El Cavana Bandung pada tahun 2012-2015.

\section{Variabel Penelitian}

Pengertian variabel seperti yang dikemukakan Sugiyono dalam bukunya Metode Penelitian Administrasi (2003:38) yaitu: —Variabel dapat didefinisikan sebagai suatu atribut atau sifat atau nilai dari orang, obyek atau kegiatan yang mempunyai variasi tertentu yang diterapkan oleh peneliti untuk dipelajari dan kemudian ditarik kesimpulannyall.

Variabel yang digunakan penulis adalah variabel bebas (independen) yaitu variabel yang mempengaruhi atau yang menjadi sebab perubahannya atau timbulnya variabel dependen (terikat).

\section{Operasionalisasi Variabel}

Matriks operasionalisasi variabel penelitiannya adalah sebagai berikut: 
Tabel 1. Matriks Operasionalisasi Variabel

\begin{tabular}{|c|c|c|c|c|c|}
\hline \multicolumn{2}{|c|}{$\begin{array}{c}\text { Variabel } \\
\text { Bebas } \\
\end{array}$} & $\begin{array}{c}\text { Sub } \\
\text { Variabel }\end{array}$ & Indikator & Skala & $\begin{array}{c}\text { Sumber } \\
\text { Data }\end{array}$ \\
\hline \multirow{3}{*}{\multicolumn{2}{|c|}{$\begin{array}{l}\text { Metode } \\
\text { Kuantitatif }\end{array}$}} & Naive & $F_{t}=A_{t-1}$ & Ratio & \multirow{6}{*}{$\begin{array}{c}\text { Dokume } \\
\text { ntasi }\end{array}$} \\
\hline & & $\begin{array}{l}\text { Moving } \\
\text { Average }\end{array}$ & $\begin{array}{c}F_{t}=A_{t-1}+A_{t-} \\
2+\ldots+A_{t-n} \\
\end{array}$ & Ratio & \\
\hline & & & $n$ & & \\
\hline \multirow{3}{*}{\multicolumn{2}{|c|}{$\begin{array}{l}\text { - Runtut } \\
\text { Waktu } \\
\text { (Time } \\
\text { Series } \\
\text { Method) }\end{array}$}} & $\begin{array}{l}\text { Exponential } \\
\text { Smoothing }\end{array}$ & $\begin{array}{c}F_{t}=F_{t-1}+\alpha\left(A_{t-1}\right. \\
- \\
\left.F_{t-1}\right)\end{array}$ & Ratio & \\
\hline & & & $b=n \underset{\Sigma X . Y}{\Sigma} \bar{\Sigma}-\Sigma X$. & & \\
\hline & & $\begin{array}{l}\text { Irena } \\
\text { Projection }\end{array}$ & $n \Sigma X^{2}-(\Sigma X)^{2}$ & Ratio & \\
\hline \multicolumn{6}{|c|}{ Keterangan: } \\
\hline$F_{t}$ & \multicolumn{5}{|c|}{$=$ nilai ramalan periode $\mathrm{t}$} \\
\hline$t$ & \multicolumn{5}{|c|}{$=$ periode waktu yang akan diramal } \\
\hline$A_{t-1}$ & \multicolumn{5}{|c|}{$=$ nilai aktual periode $\mathrm{t}-1$} \\
\hline$n$ & \multicolumn{5}{|c|}{$=$ sejumlah $(\mathrm{n})$ banyaknya order } \\
\hline$F_{t-1}$ & \multicolumn{5}{|c|}{$=$ nilai ramalan periode $\mathrm{t}-1$} \\
\hline$\alpha$ & \multicolumn{5}{|c|}{$=$ konstanta penghalus (pembobot) $(0 \leq \alpha \leq 1)$} \\
\hline$b$ & \multicolumn{5}{|c|}{$=$ kemiringan garis regresi } \\
\hline$\Sigma$ & \multicolumn{5}{|c|}{$=$ tanda penjumlahan total (sum) } \\
\hline$X$ & \multicolumn{5}{|c|}{ = nilai variabel X (variabel bebas) } \\
\hline$\underline{Y}$ & \multicolumn{5}{|c|}{$=$ nilai variabel $\mathrm{Y}$ (variabel terikat) } \\
\hline$\underline{X}$ & \multicolumn{5}{|c|}{$=$ rata-rata nilai $X$} \\
\hline$Y$ & \multicolumn{5}{|c|}{$=$ rata-rata nilai $\mathrm{Y}$} \\
\hline$\hat{Y}$ & \multicolumn{5}{|c|}{$=$ nilai terhitung dari variabel yang diprediksi } \\
\hline$a$ & \multicolumn{5}{|c|}{$=$ persilangan sumbu y } \\
\hline & \multicolumn{5}{|c|}{$=$ variabel waktu } \\
\hline
\end{tabular}

Sumber: 1. Jay Heizer dan Barry Render dalam buku Operations Management.

2. John E. Hanke dan Dean W. Wichern dalam buku Business Forecasting.

\section{Teknik Pengumpulan Data}

Menurut sumber data yang penulis dapatkan, maka data yang digunakan merupakan data sekunder, yaitu berupa:

1) Studi Dokumentasi

Berupa pengumpulan data dari lapangan tempat penulis melakukan penelitian berupa dokumen-dokumen maupun berkas-berkas yang diperlukan.

2) Studi Kepustakaan

Mempelajari teori-teori yang berhubungan dengan permasalahan yang diteliti sehingga dapat membandingkan dengan kondisi aktual yang terjadi di lapangan. 


\section{Teknik Analisis Data}

Dalam melakukan analisa forecast tingkat huni kamar di Hotel EL Cavana Bandung. Penulis menggunakan metode kuantitatif dengan pendekatan analisis runtut waktu atau time series. Dalam buku Operations Management (2006:513), Chase, Jacobs, dan Aquilano menyebutkan bahwa: "Time series analysis is a type of forecast in which data relating to past demand are used to predict future demand". Hal senada pun dikemukakan oleh Krajewski, Ritzman, dan Malhorta dalam buku Operations Management (2007:505), menyebutkan bahwa: "Time series is a repeated observation of demand for a service or product in their order of occurrence form a pattern".

Selanjutnya, dibutuhkan sebuah pendekatan untuk mencari tingkat keakuratan masing-masing komponen metode time series. Pendekatan yang dipakai adalah MAPE (Mean Absolute Percentage Error). John E. Hanke dan Dean W. Wichern dalam bukunya Business Forecasting (2005:79-80) menyebutkan bahwa:

The Mean Absolute Percentage Errors provides an indication of how large the forecast errors are in comparison to the actual values of the series. Sometimes it is more useful to compute the forecasting errors in terms of percentage rather than amounts. MAPE is computed by finding the absolute error in each period, and then averaging these absolute percentage errors. This approach is useful when the size or magnitude of the forecast variable is important in evaluating the accuracy of the forecast.

$$
\begin{aligned}
& P E_{i}=\frac{(\text { aktual }- \text { ramalan })}{\text { aktual }} \\
& M A P E=\frac{\sum\left(P E_{i}\right)}{n}
\end{aligned}
$$

Untuk menganalisis data-data yang diperoleh dalam penelitian ini, maka digunakanlah teknik Analisis Varian Satu Jalan (One Way Anova). Menurut Sugiyono dalam bukunya Metode Penelitian Administratif (2005:232), perumusannya adalah sebagai berikut:

$$
\mathrm{F}=\frac{\text { Varian Terbesat }}{\text { Varian Terkecil }}
$$


Atau dengan rumus sebagai berikut:

\begin{tabular}{|c|c|c|c|c|}
\hline \multirow{2}{*}{$\mathrm{F}=$} & & $\sum_{i=1}^{k}$ & \multicolumn{2}{|l|}{$n_{i}\left(Y_{i}-Y\right)^{2} /(k-1)$} \\
\hline & $\sum_{i=1}^{k}$ & $\begin{array}{l}\mathrm{n}_{\mathrm{i}} \\
\sum_{\mathrm{j}=1}\end{array}$ & $\left(Y_{i j}-Y_{i}\right)^{2} /$ & $\left(n_{i}-1\right)$ \\
\hline
\end{tabular}

Dengan keterangan:

$\mathrm{Y}_{\mathrm{ij}} \quad=$ data ke-j dalam sample ke-i

$\mathrm{i} \quad=1,2, \ldots \ldots ., \mathrm{k}$

$\mathrm{j} \quad=1,2, \ldots \ldots . ., \mathrm{k}$

$\mathrm{n}_{\mathrm{i}} \quad=$ ukuran sample dari populasi ke-i

$\mathrm{Y}_{\mathrm{i}}=\sum_{\mathrm{J}=1}^{\mathrm{ni}} \quad \mathrm{Y}_{\mathrm{ij}} / \mathrm{n}_{\mathrm{i}}=$ Rata-rata untuk sampel ke-i $\mathrm{J}=1$

$\mathrm{Y}=\sum_{\mathrm{I}=1}^{\mathrm{k}} \sum_{\mathrm{j}=1}^{\mathrm{ni}} \quad \mathrm{Y}_{\mathrm{ij}} / \sum_{\mathrm{i}=1}^{\mathrm{k}} \quad \mathrm{n}_{\mathrm{i}}=$ Rata-rata untuk semua data

\section{HASIL DAN PEMBAHASAN}

Berdasarkan informasi-informasi, serta dokumentasi yang telah didapatkan penulis, berikutnya adalah beberapa tabel sebagai data awal sumber bahan acuan penelitian, yang mana salah satunya berikut ini berupa tabel perbandingan besar aktual jumlah kamar terjual dengan forecast yang telah dibuat pihak hotel EL Cavana sebelumnya, selama 3 tahun 6 bulan terakhir pada tahun 2012 sampai 2015.

Tabel 2. Perbandingan Aktual dan Forecast Jumlah Kamar Terjual di Hotel EL Cavana Bandung Tahun 2012-2015

\begin{tabular}{|c|c|c|c|c|c|}
\hline \multirow{2}{*}{\multicolumn{2}{|c|}{ YEAR }} & \multicolumn{2}{|c|}{$\begin{array}{l}\text { NUMBER OF } \\
\text { ROOM SOLD }\end{array}$} & \multirow{2}{*}{$\begin{array}{c}\text { VARIANCE } \\
\text { (e) }\end{array}$} & \multirow{2}{*}{$\begin{array}{l}\text { PERCENTAGE } \\
\text { VARIANCE (e) }\end{array}$} \\
\hline & & Actual & Forecast & & \\
\hline \multirow{3}{*}{2012} & 1 st Semester & 3992 & 4900 & 908 & $22,75 \%$ \\
\hline & $2^{\text {nd }}$ Semester & 3964 & 4957 & 993 & $25,05 \%$ \\
\hline & TOTAL & 7956 & 9857 & 1901 & $23,89 \%$ \\
\hline \multirow{3}{*}{2013} & $1^{\text {st }}$ Semester & 4040 & 5103 & 1063 & $26,31 \%$ \\
\hline & $\begin{array}{c}2^{\text {nd }} \\
\text { Semester }\end{array}$ & 4059 & 5189 & 1130 & $27,84 \%$ \\
\hline & TOTAL & 8099 & 10292 & 2193 & $27,08 \%$ \\
\hline \multirow[b]{2}{*}{2014} & $1^{\text {st }}$ Semester & 4146 & 5159 & 1013 & $24,43 \%$ \\
\hline & $\begin{array}{c}2^{\text {nd }} \\
\text { Semester }\end{array}$ & 4223 & 5248 & 1025 & $24,27 \%$ \\
\hline
\end{tabular}




\begin{tabular}{|rrrccc|}
\hline & TOTAL & $\mathbf{8 3 6 9}$ & $\mathbf{1 0 4 0 7}$ & $\mathbf{2 0 3 8}$ & $\mathbf{2 4 , 3 5 \%}$ \\
$\mathbf{2 0 1 5}$ & $1^{\text {st }}$ Semester & 4348 & 5215 & 867 & $19,94 \%$ \\
\hline
\end{tabular}

Sumber: Front Office Department Hotel EL Cavana, Februari 2016.

Dari tabel di atas, dapat kita lihat bahwa perbedaan antara aktual jumlah kamar terjual dengan forecast yang telah dibuat sebelumnya (varian), berada dalam jumlah yang cukup besar. Dimulai dari tahun 2012, besar persentase varian yang ada yaitu sebesar 23,89\%, berjumlah 1901 kamar, sedangkan pada tahun 2013 besar persentase variannya ternyata bertambah menuju angka 27,08\%, berjumlah 2193 kamar. Pada tahun 2014, terdapat penurunan persentase varian menuju angka 24,35\%, berjumlah 2038 kamar. Sekarang ini, pada tahun 2015, tercatat pada periode semester I, besar varian yang ada sebesar $19,94 \%$, berjumlah 867 kamar.

Proses penerapan forecast jumlah kamar terjual, sebelumnya dimulai dari menentukan berapa besar forecast untuk tingkat huni kamar pada periode waktu yang ditentukan. Pihak yang berkepentingan menetapkan forecast tersebut (manajemen hotel EL Cavana), menilai bahwa besar forecast yang ditetapkan sekarang atau nantinya sebagai sebuah sasaran organisasi yang hendak dicapai dengan cara merumuskan strategi-strategi yang diperlukan melalui beberapa aktivitas -aktivitas organisasi baik operasional, administrasi dan lain sebagainya. Sebagai salah satu pendekatan dalam melihat besar pendapatan pada Rooms Department, berikut adalah beberapa tabel perbandingan pencapaian aktual tingkat huni kamar terhadap forecast yang telah dibuat pihak hotel EL Cavana sebelumnya, selama 3 tahun 6 bulan terakhir pada tahun 2012 sampai tahun 2015.

Tabel 3. Perbandingan Aktual dan Forecast Tingkat Huni Kamar Di Hotel EL Cavana Bandung Tahun 2012

\begin{tabular}{|rccc|}
\hline Month & $\begin{array}{c}\text { Actual } \\
\text { Occupancy } \\
(\mathbf{\%})\end{array}$ & $\begin{array}{c}\text { Forecast } \\
\text { Occupancy } \\
(\mathbf{\%})\end{array}$ & $\begin{array}{c}\text { Variance } \\
(\mathbf{e})\end{array}$ \\
\hline January & 66,9 & 80 & 13,1 \\
February & 53,2 & 65 & 11,8 \\
March & 51,9 & 65 & 13,1 \\
April & 47,4 & 65 & 17,6 \\
May & 50,6 & 65 & 14,4 \\
June & 76,3 & 85 & 8,7 \\
July & 59,1 & 80 & 20,9 \\
August & 51,2 & 65 & 13,8 \\
September & 49,8 & 65 & 15,2 \\
Oktober & 52,6 & 65 & 12,4 \\
November & 54,8 & 65 & 10,2 \\
December & 72,4 & 85 & 12,6 \\
\hline
\end{tabular}

Sumber: Front Office Department Hotel EL Cavana, Februari 2016. 
Berdasarkan tabel perbandingan diatas, besar rata-rata aktual tingkat huni kamar pada tahun 2012 yaitu sebesar 57,18\%, sedangkan besar rata-rata forecast tingkat huni kamarnya yaitu sebesar 70,83\%. Maka besar rata-rata variannya yaitu sebesar $13,65 \%$.

Tabel 4. Perbandingan Aktual dan Forecast Tingkat Huni Kamar Di Hotel EL Cavana Bandung Tahun 2013

\begin{tabular}{|rccc|}
\hline Month & $\begin{array}{c}\text { Actual } \\
\text { Occupancy (\%) }\end{array}$ & $\begin{array}{c}\text { Forecast } \\
\text { Occupancy (\%) }\end{array}$ & $\begin{array}{c}\text { Variance } \\
\text { (e) }\end{array}$ \\
\hline January & 65,2 & 80 & 14,8 \\
February & 57,4 & 70 & 12,6 \\
March & 51,7 & 70 & 18,3 \\
April & 50,2 & 70 & 19,8 \\
May & 51,0 & 70 & 19 \\
June & 77,1 & 85 & 7,9 \\
July & 59,7 & 80 & 20,3 \\
August & 51,3 & 70 & 18,7 \\
September & 53,5 & 70 & 16,5 \\
October & 53,1 & 70 & 16,9 \\
November & 55,6 & 70 & 14,4 \\
December & 74,9 & 85 & 10,1 \\
\hline
\end{tabular}

Sumber: Front Office Department Hotel EL Cavana, Februari 2016.

Berdasarkan tabel perbandingan diatas, besar rata-rata aktual tingkat huni kamar pada tahun 2013 yaitu sebesar 58,39\%, sedangkan besar rata-rata forecast tingkat huni kamarnya yaitu sebesar $74,17 \%$. Maka besar rata-rata variannya yaitu sebesar $15,78 \%$. Selanjutnya, tabel perbandingan aktual dan forecast tingkat huni kamar pada tahun 2013, dapat dilihat pada halaman berikut:

Tabel 5. Perbandingan Aktual Dan Forecast Tingkat Huni Kamar Di Hotel EL Cavana Bandung Tahun 2014

\begin{tabular}{|rccc|}
\hline Month & $\begin{array}{c}\text { Actual } \\
\text { Occupancy }(\%)\end{array}$ & $\begin{array}{c}\text { Forecast } \\
\text { Occupancy } \\
(\mathbf{\%})\end{array}$ & $\begin{array}{c}\text { Variance } \\
(\mathbf{e})\end{array}$ \\
\hline January & 65,8 & 82,5 & 16,7 \\
February & 60,7 & 72,5 & 11,8 \\
March & 50,4 & 70 & 19,6 \\
April & 52,1 & 70 & 17,9 \\
May & 56,3 & 70 & 13,7 \\
June & 76,7 & 85 & 8,3 \\
July & 64,6 & 82,5 & 17,9 \\
August & 54,9 & 72,5 & 17,6 \\
September & 51,8 & 70 & 18,2 \\
\hline
\end{tabular}




\begin{tabular}{|cccc|}
\hline Month & $\begin{array}{c}\text { Actual } \\
\text { Occupancy }(\%)\end{array}$ & $\begin{array}{c}\text { Forecast } \\
\text { Occupancy } \\
(\%)\end{array}$ & $\begin{array}{c}\text { Variance } \\
(\mathbf{(})\end{array}$ \\
\hline Oktober & 50,1 & 70 & 19,9 \\
November & 63,5 & 70 & 6,5 \\
December & 77,3 & 85 & 7,7 \\
\hline
\end{tabular}

Sumber: Front Office Department Hotel EL Cavana, Februari 2016.

Berdasarkan tabel perbandingan diatas, besar rata-rata aktual tingkat huni kamar pada tahun 2014 yaitu sebesar 60,35\%, sedangkan besar rata-rata forecast tingkat huni kamarnya yaitu sebesar $75 \%$. Maka besar rata -rata variannya yaitu sebesar 14,65\%. Selanjutnya, tabel perbandingan aktual dan forecast tingkat huni kamar pada semester I tahun 2015, dapat dilihat pada halaman berikutnya:

Tabel 6. Perbandingan Aktual dan Forecast Tingkat Huni Kamar Di Hotel EL Cavana Bandung Tahun 2015

\begin{tabular}{|rccc|}
\hline \multicolumn{1}{|c}{ Month } & $\begin{array}{c}\text { Actual } \\
\text { Occupancy (\%) }\end{array}$ & $\begin{array}{c}\text { Forecast } \\
\text { Occupancy }(\%)\end{array}$ & $\begin{array}{c}\text { Variance } \\
(\mathbf{e})\end{array}$ \\
\hline July & 71,0 & 82,5 & 11,5 \\
August & 63,1 & 75 & 11,9 \\
September & 53,4 & 70 & 16,6 \\
October & 50,9 & 70 & 19,1 \\
November & 61,6 & 70 & 8,4 \\
December & 79,4 & 87,5 & 8,1 \\
\hline
\end{tabular}

Sumber: Front Office Department Hotel EL Cavana, Februari 2015.

Berdasarkan tabel perbandingan diatas, besar rata-rata aktual tingkat huni kamar pada semester I tahun 2015 yaitu sebesar 63,23\%, sedangkan besar ratarata forecast tingkat huni kamarnya yaitu sebesar 75,83\%. Maka besar rata-rata variannya yaitu sebesar $12,60 \%$.

Berdasarkan data tersebut diatas dapat dilihat bahwa pencapaian tingkat huni kamar, bisa dikatakan sedikit jauh dengan yang telah diharapkan sebelumnya, tidak tercapainya tingkat huni kamar dengan besar variance yang berada di kisaran 12\%-15\%, diduga disebabkan karena tidak sesuainya penggunaan metode peramalan dalam menentukan target yang hendak dicapai oleh hotel EL Cavana Bandung. Forecasting merupakan salah satu bagian penting dalam perencanaan organisasi agar pihak manajemen dapat memperkirakan kejadian-kejadian di masa mendatang, dengan tujuan terciptanya nilai-nilai mode operasi yang efektif dan efisien. Oleh karena hal tersebut, prakiraan atau peramalan yang baik adalah peramalan yang menghasilkan prediksi yang nilainya mendekati nilai aktual pada waktu akan diramalkan. 


\section{A. Analisis Mengenai Penerapan Metode Peramalan Dalam Menetapkan Target Tingkat Huni Kamar}

Kegiatan perencanaan sebagai salah satu fungsi manajemen, memiliki tujuan diantaranya untuk melakukan penetapan target. Dimana dalam menetapkan target tersebut kita dapat menggunakan peramalan (forecasting) sebagai salah satu alat dan teknik perencanaan dalam menilai lingkungan dan merupakan bagian penting dari perencanaan organisasi agar dapat memperkirakan kejadian di masa mendatang dengan efektif dan akurat.. Peramalan yang baik adalah peramalan yang dapat menghasilkan prediksi dimana nilainya diharapkan mendekati nilai aktual pada kurun waktu yang akan diramalkan.

Berangkat dari beberapa referensi maupun kutipan-kutipan yang ada sebelumnya, dalam situasi aplikasi peramalan yang ditujukan, yaitu peramalan permintaan, maka metode peramalan yang dianjurkan adalah metode peramalan runtut waktu atau time series method. Metode peramalan runtut waktu ini terbagi menjadi empat teknik peramalan yaitu: nä̈ve, moving average, exponential smoothing dan trend projections (regression).

Sedangkan penetapan target tingkat huni kamar yang dilakukan oleh pihak manajemen Hotel EL Cavana Bandung dapat dikatakan bersifat subjektif, karena dilakukan berdasarkan jalur diskusi antara pihak-pihak yang terkait dimana dalam hal ini dilakukan antara seorang Hotel Manager dengan General Manager dan Owner dari Hotel EL Cavana Bandung itu sendiri. Peramalan yang dibuat biasanya memiliki rentang waktu 6 bulan sampai dengan 1 tahun. Artinya pihak manajemen yang terkait membuat forecasting dengan variabel target tingkat huni kamar untuk setiap satu atau dua semester, yang biasanya ditetapkan secara formal tiga atau empat bulan sebelumnya.

Dengan menimbang pencapaian aktual tingkat huni kamar berdasarkan periode-periode sebelumnya, serta penilaian akan lingkungan Hotel EL Cavana itu sendiri, forecast yang dibuat selalu mencerminkan peningkatan target yang diharapkan. Adanya dorongan dari General Manager dan pihak Owner agar aktual tingkat huni kamar bisa menaik setiap perode waktunya, sesuai dengan visi perusahaan yang diharapkan pihak Owner itu sendiri, seorang Hotel Manager pada akhirnya menetapkan target yang lebih tinggi pada periode kelanjutan waktunya, dengan berusaha mengintegrasikan fungsi-fungsi manajemen serta merumuskan strategi yang diperlukan yang ada agar perusahaan dapat mencapai sasaran perusahaan sesuai dengan target yang diharapkan sebelumnya.

Namun dengan menggunakan pendekatan yang bersifat subjektif, terjadi nilai varian antara aktual dan forecast tingkat huni kamar yang cukup tinggi. Hal ini disebabkan karena pendekatan yang dilakukan oleh pihak manajemen melalui metode subjektif tersebut dinilai kurang tepat.

Diperlukan langkah-langkah terpadu dalam penerapan metode peramalan untuk mendapatkan hasil peramalan yang memiliki tingkat akurasi paling baik dan paling akurat. Terdapat sepuluh langkah yang dipandang strategis untuk menetapkan sebuah peramalan, tahapan tersebut diantaranya berupa pengidentifikasian tujuan peramalan, penghitungan dengan metode yang kiranya sesuai, sampai memonitor hasil peramalan. Setelah penulis melakukan pengkajian 
terhadap tahapan dalam penerapan peramalan di Hotel EL Cavana Bandung, dapat diketahui hal-hal yang sesuai dengan teori yang dimaksud dan terdapat pula halhal yang tidak sesuai dengan teori tersebut.

Langkah pertama adalah mengidentifikasikan tujuan peramalan. Langkah ini telah dilakukan oleh pihak manajemen Hotel EL Cavana dengan mengindentifikasikan tujuan peramalan berupa penetapan target tingkat huni kamar dimana diharapkan besarnya target tersebut bisa mendekati nilai aktual yang akan terjadi.

Langkah yang kedua adalah mengumpulkan data- data historis. Langkah ini pun telah dilakukan oleh pihak manajemen Hotel EL Cavana dalam membuat peramalan, pengumpulan data-data historis yang dibutuhkan bertujuan agar pihak manajemen dapat berkaca dari apa yang telah dicapai pada periode sebelumnya untuk kemudian diproyeksikan ke masa mendatang.

Langkah yang ketiga adalah mengidentifikasikan jenis atau pola datanya. Pihak manajemen Hotel EL Cavana melakukan langkah ketiga ini dengan mengidentifiksikan data tingkat huni kamar ke dalam pola data musiman.

Langkah keempat adalah memilih teknik peramalan yang kiranya sesuai untuk diterapkan. Mengenai langkah ini, pihak manajemen Hotel EL Cavana melakukannya dengan memilih pendekatan subjektif disertai dengan penyesuaian informasi-informasi kualitatif untuk menetapkan target tingkat huni kamar.

Langkah kelima adalah menghitung peramalan periode-periode waktu yang lalu dengan teknik yang telah dipilih sebelumnya. Berdasarkan analisa penulis, langkah ini tidak pihak manajemen Hotel EL Cavana lakukan, karena pihak manajemen yang bersangkutan cenderung langsung menghitung peramalan untuk rentang waktu yang akan datang.

Langkah keenam adalah meninjau dan menghitung keakuratan peramalan tersebut. Karena langkah sebelumnya tidak pihak manajemen Hotel EL Cavana lakukan, maka langkah keenam ini pun tidak dilakukan oleh pihak manajemen yang bersangkutan.

Langkah ketujuh adalah mempertanyakan akurasi peramalan tersebut, apakah dapat diterima atau tidak. Yang terjadi di Hotel EL Cavana, langkah ini tidak dilakukan oleh pihak manajemen yang bersangkutan. Karena langkah kelima sampai dengan langkah ketujuh merupakan satu kesinambungan. Maka apabila satu langkah tidak dilakukan tentu saja akan berdampak sama terhadap dua langkah lainnya.

Langkah selanjutnya; langkah kedelapan adalah meramal horizon waktu yang diinginkan dengan teknik peramalan yang telah disetujui sebelumnya. Dalam hal ini, pihak manajemen Hotel EL Cavana melakukan langkah tersebut dengan meramal target tingkat huni kamar setiap bulan dalam kurun waktu satu atau dua semester, dengan menggunakan pendekatan subjektif.

Langkah kesembilan adalah menyesuaikan peramalan yang dihasilkan dengan menambahkan informasi-informasi kualitatif. Yang terjadi di Hotel EL Cavana, pihak manajemen yang bersangkutan melakukan langkah ini dengan meramal target tingkat huni kamar melalui pendekatan subjektif disertai dengan penyesuaian berupa penambahan informasi-informasi kualitatif yang diperlukan. 
Langkah yang terakhir, langkah kesepuluh adalah memonitor hasil dari peramalan tersebut. Menurut analisa penulis langkah ini telah dilakukan oleh pihak manajemen Hotel EL Cavana, khususnya oleh seorang Hotel Manager. Kegiatan monitoring ini bertujuan untuk melihat sejauh mana perkembangan akan hasil yang telah dicapai, dan selanjutnya mengambil tindakan-tindakan yang diperlukan, sebagaimana layaknya tugas seorang manager.

Adapun realisasi target dan aktual tingkat huni kamar dan forecasting oleh pihak manajemen Hotel EL Cavana Bandung dapat dijelaskan sebagai berikut.

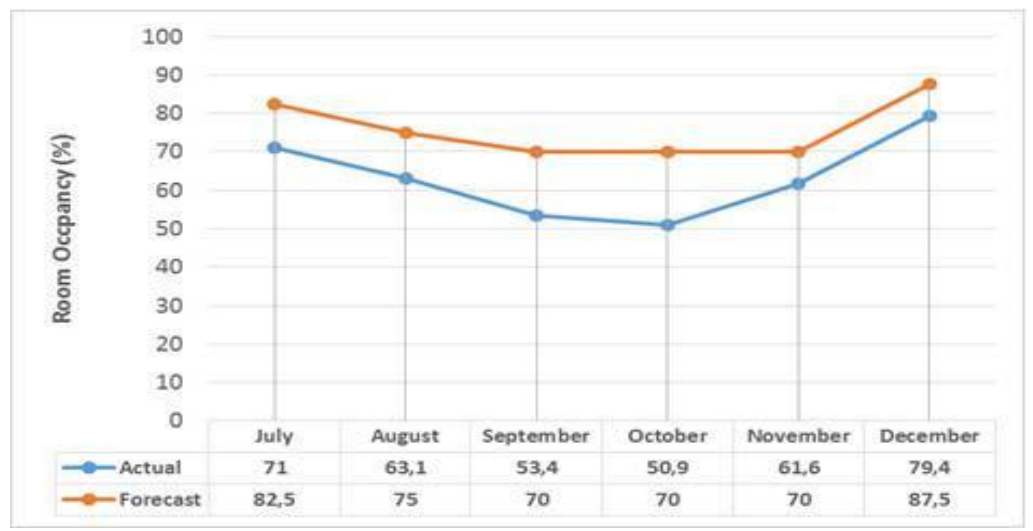

Sumber: Data Olahan Penulis, Maret 2016.

\section{Grafik 1. Aktual dan Forecast Tingkat Huni Kamar di Hotel EL Cavana Bandung Semester II Tahun 2015}

Pada grafik di atas terdapat beberapa pola yang dihasilkan dari penetapan target tingkat huni kamar oleh pihak manajemen Hotel EL Cavana Bandung. Secara keseluruhan realisasi aktual tingkat huni kamar yang terjadi berada dibawah target tingkat huni kamar sebelumnya, dengan tingkat pencapaian aktual tingkat huni kamar sebesar $83,38 \%$. Sedangkan besar rata -rata varian yang dihasilkan dari penetapan target tingkat huni kamar oleh pihak manajemen Hotel EL Cavana Bandung adalah sebesar 12,60\%.

Metode peramalan yang diujikan yaitu nä̈ve, moving average, exponential smoothing, dan trend projections, dengan menggunakan data-data yang sama menghasilkan varian yang relatif jauh lebih kecil. Hal tersebut dapat terlihat pada grafik realisasi target tingkat huni kamar seperti berikut. 


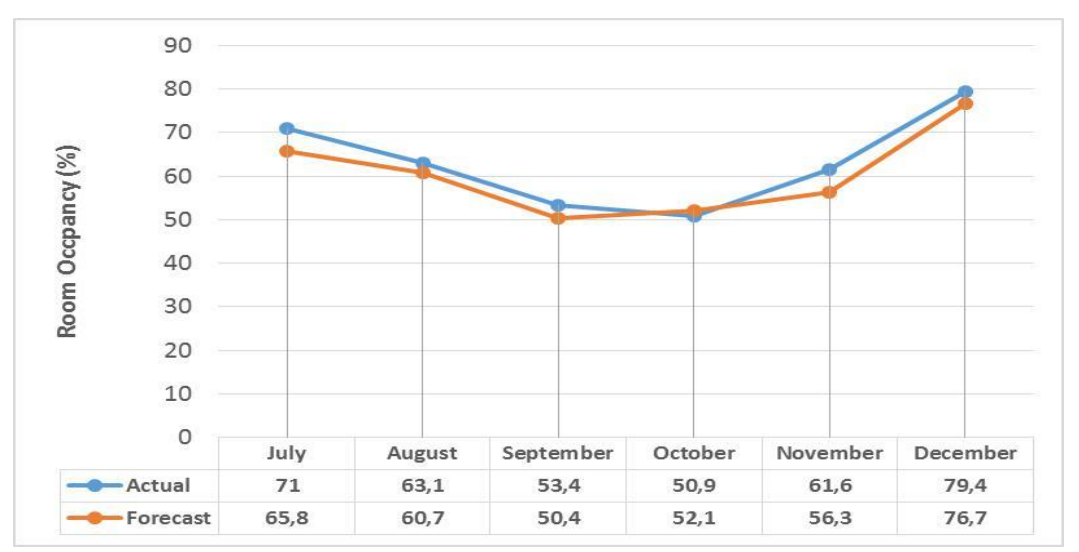

Sumber: Data Olahan Penulis, Maret 2016.

\section{Grafik 2. Aktual dan Forecast Tingkat Huni Kamar Metode Naïve Di Hotel EL Cavana Bandung Semester II Tahun 2015}

Jika dibandingkan dengan penetapan target oleh pihak manajemen Hotel EL Cavana Bandung, metode naive menunjukan bahwa nilai target mendekati aktual sebagaimana terlihat pada grafik di atas. Pola-pola yang diramalkan tidak berbeda jauh dengan keadaan aktual. Tingkat pencapaian tingkat huni kamar dengan metode ini adalah sebesar $95,41 \%$. Dengan metode ini rata-rata varian antara target dan aktual yang dihasilkan adalah sebesar 3,30\%.

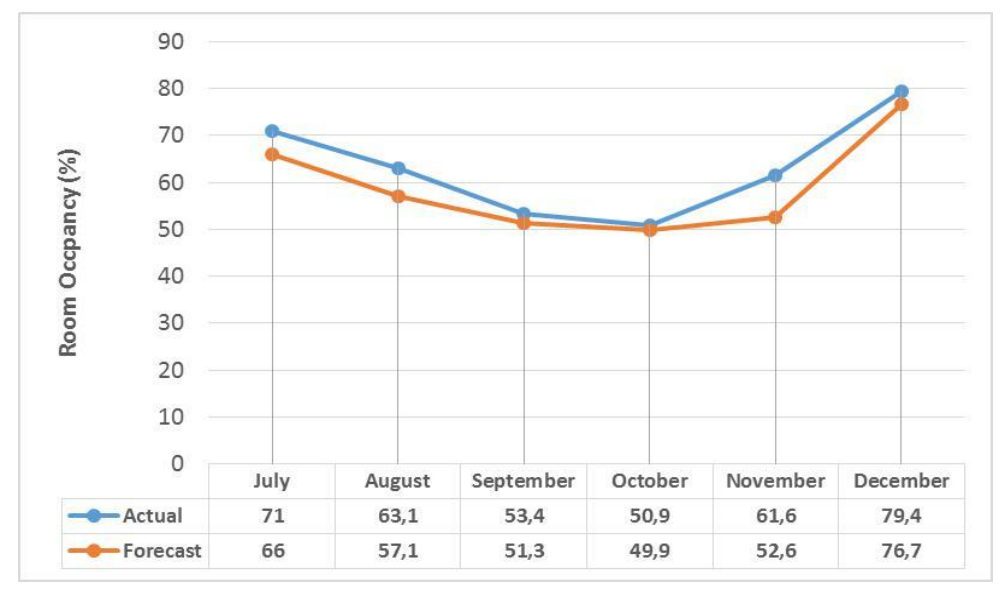

Sumber: Data Olahan Penulis, Maret 2016.

\section{Grafik 3. Aktual dan Forecast Tingkat Huni Kamar Metode Moving Average di Hotel EL Cavana Bandung Semester II Tahun 2015}

Sedangkan dengan menggunakan metode moving average, pola yang dihasilkan masih lebih baik dibandingkan dengan penetapan target oleh pihak manajemen Hotel EL Cavana Bandung. Secara keseluruhan tingkat pencapaian 
aktualnya adalah sebesar 93,21\%. Dengan metode ini besar rata-rata variannya adalah sebesar $4,30 \%$.

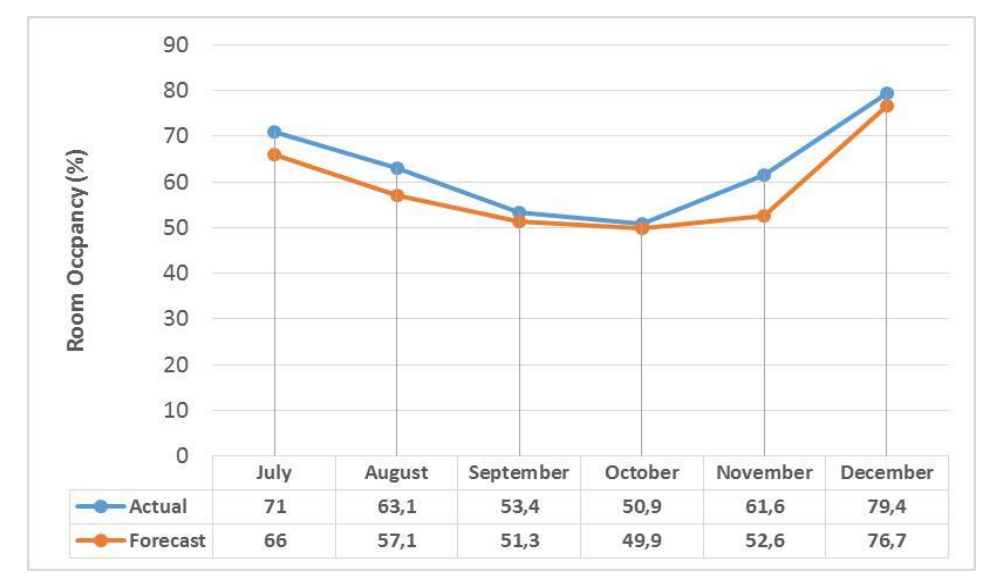

Sumber: Data Olahan Penulis, Maret 2016.

\section{Grafik 4. Aktual dan Forecast Tingkat Huni Kamar Metode Exponential Smoothing $(\alpha=0,3)$ di Hotel El Cavana Bandung Semester II Tahun 2015}

Dengan menggunakan metode exponential smoothing $(\alpha=0,3)$, pola yang dihasilkan cenderung mirip dengan dengan pola pihak manajemen Hotel EL Cavana Bandung, namun besar varian yang ada cenderung lebih kecil. Secara keseluruhan tingkat pencapaian tingkat huni kamar aktual pada metode ini adalah sebesar $89,56 \%$. Dengan besar rata-rata varian sebesar 7,37\%.

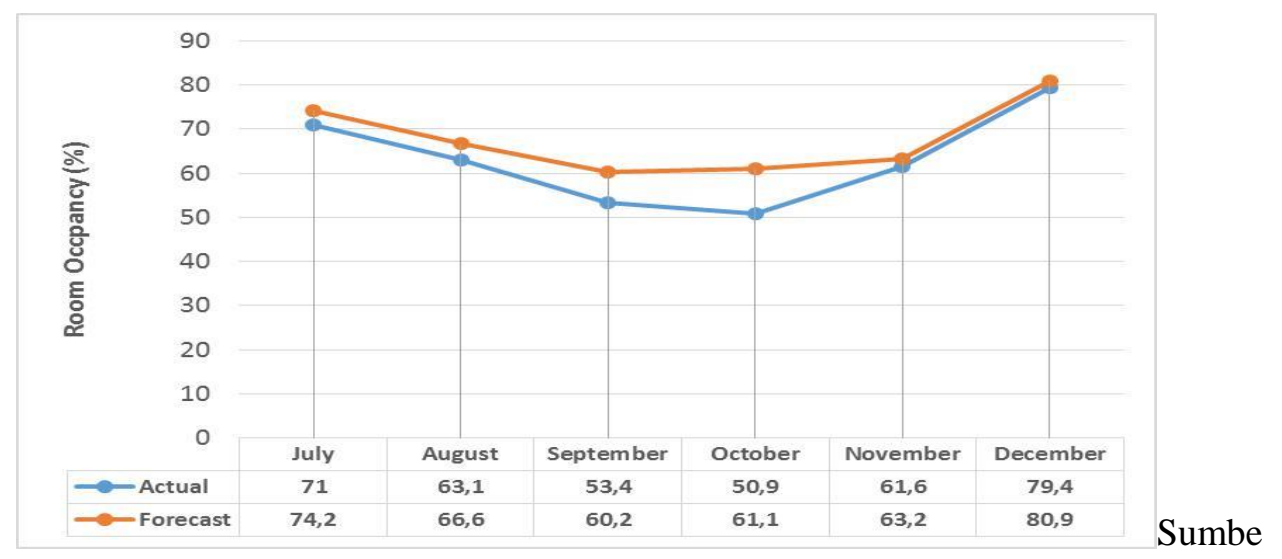

r: Data Olahan Penulis, Maret 2016.

Grafik 5. Aktual Dan Forecast Tingkat Huni Kamar Metode Exponential Smoothing $(\alpha=0,5)$ di Hotel El Cavana Bandung Semester II Tahun 2015

Dengan menggunakan metode exponential smoothing $(\alpha=0,5)$, pola yang dihasilkan lebih baik dibandingkan metode exponential smoothing sebelumnya. 
Secara keseluruhan tingkat pencapaian tingkat huni kamar aktual pada metode ini adalah sebesar 93,43\%. Dengan besar rata-rata varian sebesar 4,47\%.

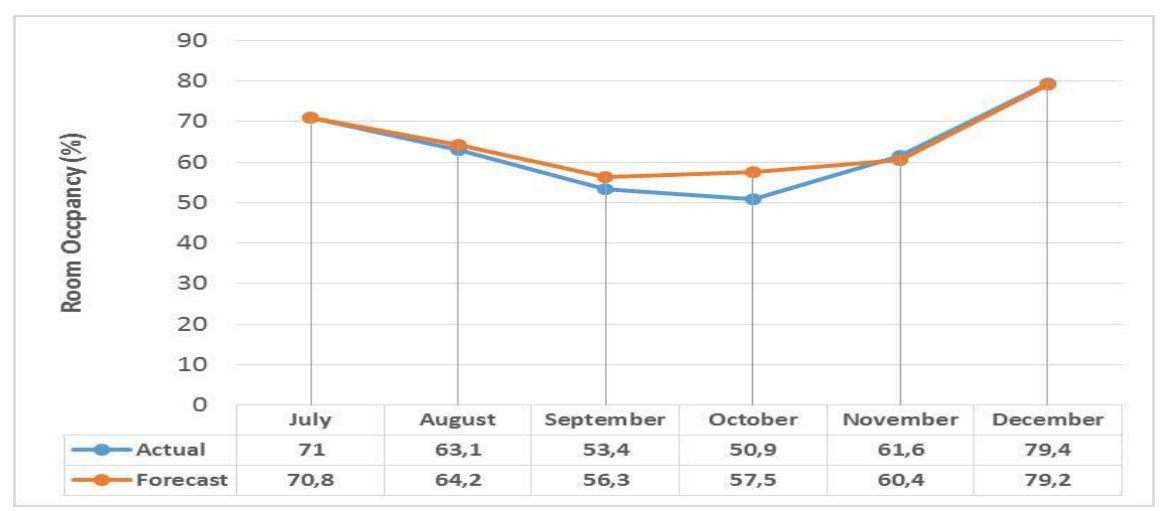

Sumber : Data Olahan Penulis, Maret 2016.

Grafik 6. Aktual Dan Forecast Tingkat Huni Kamar Metode Exponential Smoothing $(\alpha=0,7)$ di Hotel El Cavana Bandung Semester II Tahun 2015

Dengan menggunakan metode exponential smoothing $(\alpha=0,7)$, pola yang dihasilkan merupakan pola terbaik dibandingkan dengan pola-pola metode lainnya. Secara keseluruhan tingkat pencapaian tingkat huni kamar aktual pada metode ini adalah sebesar 97,68\%. Dengan besar rata-rata varian sebesar 2,03\%.

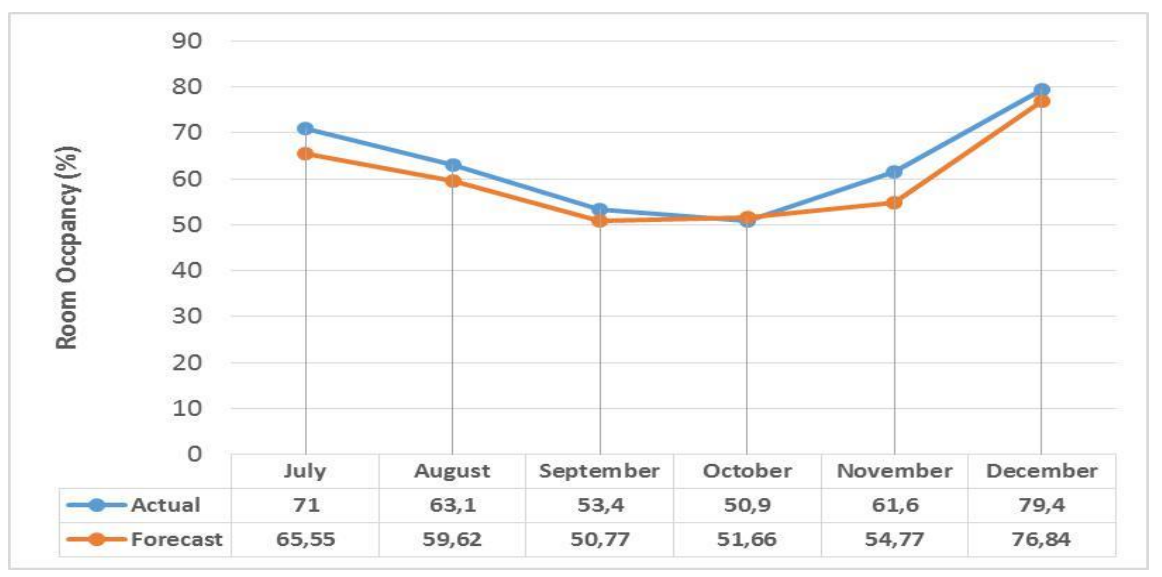

Sumber: Data Olahan Penulis, Maret 2016.

\section{Grafik 7. Aktual dan Forecast Tingkat Huni Kamar Metode Trend Projections Di Hotel EL Cavana Bandung Semester II Tahun 2016}

Sedangkan dengan menggunakan metode trend projections, pola yang dihasilkan cenderung mirip dengan pola-pola yang terdapat pada metode naive. Secara keseluruhan tingkat pencapaian tingkat huni kamar aktual pada metode ini adalah sebesar 94,69\%. Dengan besar rata-rata varian sebesar 3,62\%. Dari uraian 
diatas, maka dapat disimpulkan bahwa kesalahan penetapan target tingkat huni kamar di Hotel EL Cavana Bandung, berawal dari kesalahan dalam menentukan metode peramalan yang kiranya sesuai. Sehingga pada akhirnya dampak kesalahan tersebut, berlanjut kedalam langkah-langkah selanjutnya. Maka hal ini mengakibatkan hasil ramalan target tingkat huni kamar tersebut tidak efektif dan tidak dapat terealisasi.

\section{B. Analisis Mengenai Kajian Tingkat Ukuran Ketepatan Mean Absolute Percentage Error (MAPE) Terhadap Metode Peramalan Dalam Penetapan Target Tingkat Huni Kamar di Hotel EL Cavana Bandung}

Salah satu instrumen terpenting dalam menentukan teknik atau metode peramalan mana yang paling tepat digunakan adalah tingkat akurasi peramalan tersebut. Sehingga dengan semakin baik tingkat akurasi tersebut, maka diharpkan akan semakin kecil perbandingan antara aktual dengan target atau forecast yang telah dibuat sebelumnya. Mean Absolute Percentage Error (MAPE) merupakan alat pengukur akurasi untuk data yang khususnya berbentuk persentase. MAPE itu sendiri merupakan rata-rata tingkat kesalahan ramalan terhadap aktual yang terjadi. Selanjutnya penulis mencoba memperbandingan nilai MAPE hasil ramalan target tingkat huni kamar oleh pihak manajemen Hotel EL Cavana Bandung dengan nilai MAPE metode runtut waktu (time series): Nä̈ve, Moving Average, Exponential Smoothing, dan Trend Projections (Regression). Pada halaman berikut adalah grafik yang menngambarkan nilai $M A P E$ dari penetapan target oleh manajemen Hotel EL Cavana dan masing-masing metode runtut waktu (time series):

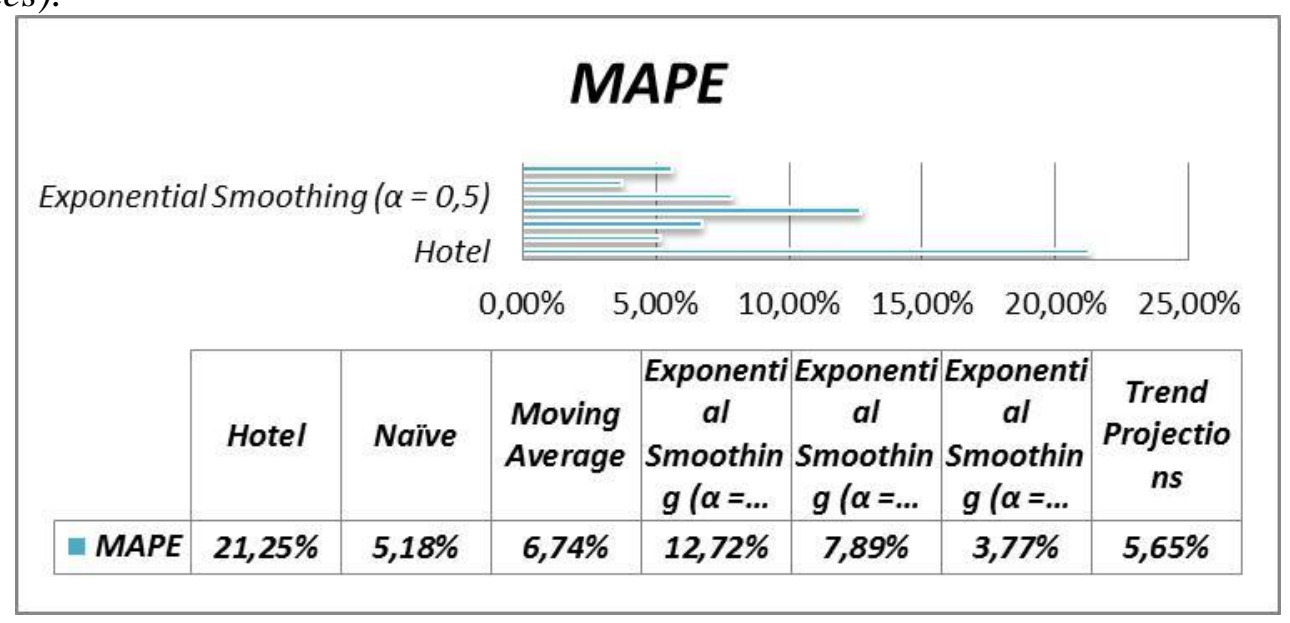

Sumber: Data Olahan Penulis, Maret 2016.

\section{Grafik 8. Grafik Perbandingan MAPE Metode Peramalan Target Tingkat Huni Kamar di Hotel EL Cavana Bandung Semester II Tahun 2015}

Berdasarkan gambar grafik diatas, nilai MAPE untuk hasil penetapan target tingkat huni kamar semester II tahun 2015 oleh pihak manajemen Hotel EL Cavana Bandung adalah sebesar 21,25\%. Berdasarkan kategori yang telah 
diuraikan sebelumnya, untuk nilai MAPE yang lebih dari 20\%, maka pendekatan hotel tersebut dapat dikategorikan "kurang baik".

Selanjutnya nilai MAPE metode runtut waktu yang pertama; naïve, adalah sebesar 5,18\%. Menurut kategori yang ada, apabila MAPE bernilai antara $0-10 \%$, maka metode naïve tersebut dapat dikategorikan "baik"

Untuk metode moving average, nilai MAPEnya adalah sebesar 6,74\%. maka metode ini dapat dikategorikan "baik". Untuk metode exponential smoothing, nilai MAPE untuk exponential smoothing dengan $(\alpha=0,3)$ adalah sebesar 12,72\%. Metode ini dapat dikategorikan "kurang baik", karena nilainya berada di antara $10-20 \%$. Sedangkan untuk metode exponential smoothing dengan $(\alpha=0,5)$, nilai MAPEnya adalah sebesar 7,89\%. Metode ini dapat dikategorikan "baik".

Untuk metode exponential smoothing dengan $(\alpha=0,7)$, Nilai MAPEnya merupakan nilai yang terkecil dibandingkan exponential smoothing sebelumnya, yaitu sebesar 3,77\%. Maka metode inipun dapat dikategorikan "baik".

Untuk metode trend projections (regression), nilai MAPEnya adalah sebesar 5,65\%. Dengan besar nilai tersebut, maka metode trend projections dapat dikategorikan "baik". Berikut adalah kesimpulan dari penghitungan nilai MAPE beserta kategorinya tersebut:
a. Hotel
$: 21,25 \% \quad$ : tidak baik
b. Nä̈ve
$: 5,18 \% \quad:$ baik
c. Moving Average
$: 6,74 \% \quad:$ baik
d. Exponential Smoothing
- $(\alpha=0,3)$
$: 12,72 \% \quad$ : kurang baik
- $(\alpha=0,5)$
$: 7,89 \% \quad$ : baik
- $(\alpha=0,7)$
$: 3,77 \% \quad:$ baik $^{*}$
e. Trend Projections (Regression)
$: 5,65 \%$
: baik

Jika dibandingkan dengan hasil peramalan pihak manajemen Hotel EL Cavana Bandung yaitu dengan MAPE sebesar 21,25\%, yang termasuk dalam kategori -kurang baikll, maka metode peramalan runtut waktu Exponential Smoothing dengan $(\alpha=0,7)$ dengan nilai MAPE sebesar $3,77 \%$, yang termasuk dalam kategori - baik\|, merupakan metode yang paling tepat karena memiliki tingkat kesalahan terkecil, yang diharapkan dapat menjadi pertimbangan bagi pihak manajemen dalam menetapkan target tingkat huni kamar yang lebih relevan dan tentunya lebih mendekati nilai aktual yang terjadi maupun yang akan terjadi nantinya.

\section{Analisis Mengenai Kebijakan Varian Metode Peramalan Dalam Penetapan Target Tingkat Huni Kamar di Hotel EL Cavana Bandung}

Varian merupakan besarnya perbedaan antara hasil aktual yang dicapai dengan target atau forecast yang telah dibuat sebelumnya. Seperti yang telah dikemukakan sebelumnya bahwa, keakuratan keseluruhan dari setiap metode peramalan (forecasting) dapat dijelaskan dengan membandingkan nilai yang 
diramal dengan nilai aktual atau nilai yang sedang diamati. Peramalan yang baik adalah yang peramalan yang menghasilkan prediksi yang nilai ramalannya mendekati nilai aktual pada waktu akan diramalkan.

Penetapan target tingkat huni kamar yang dilakukan oleh pihak manajemen Hotel EL Cavana Bandung dapat dikatakan bersifat subjektif, karena dilakukan berdasarkan jalur diskusi antara pihak-pihak yang terkait di dalamnya. Dari hasil penetapan target tingkat huni kamar pada semester II tahun 2015, dapat terlihat bahwa sesungguhnya target tersebut tidak tercapai. Besar batas toleransi varian yang diharapkan oleh hotel yaitu sebesar 10\%, namun kenyataannnya, rata-rata varian yang terjadi melebihi batas toleransi yang diharapkan.

Tabel 7. Descriptives-Metode Peramalan Target Tingkat Huni Kamar Hotel El Cavana Bandung Semester II Tahun 2015

\begin{tabular}{|c|c|c|c|c|c|c|c|}
\hline \multicolumn{8}{|l|}{ Forecast Occupancy } \\
\hline & \multirow{2}{*}{ Mean } & \multirow{2}{*}{$\begin{array}{c}\text { Std. } \\
\text { Deviation }\end{array}$} & \multirow{2}{*}{$\begin{array}{c}\text { Std. } \\
\text { Error }\end{array}$} & \multicolumn{2}{|c|}{$\begin{array}{c}\text { 95\% Confidence Interval for } \\
\text { Mean }\end{array}$} & \multirow{2}{*}{ Min. } & \multirow{2}{*}{ Max. } \\
\hline & & & & Lower Bound & Upper Bound & & \\
\hline Hotel & 75,8333 & 7,52773 & 3,07318 & 67,9335 & 83,7332 & 70,00 & 87,50 \\
\hline Naive & 60,3333 & 9,80422 & 4,00255 & 50,0444 & 70,6222 & 50,40 & 76,70 \\
\hline Moving Average & 58,9167 & 10,44403 & 4,26376 & 47,9563 & 69,8770 & 49,90 & 76,60 \\
\hline Exp. Smoothing 0,3 & 70,6000 & 7,64356 & 3,12047 & 62,5786 & 78,6214 & 64,10 & 82,50 \\
\hline Exp. Smoothing 0,5 & 67,7000 & 8,21900 & 3,35539 & 59,0747 & 76,3253 & 60,20 & 80,90 \\
\hline Exp. Smoothing 0,7 & 64,7333 & 8,81582 & 3,59904 & 55,4817 & 73,9850 & 56,30 & 79,20 \\
\hline Trend Projections & 59,8683 & 9,96524 & 4,06829 & 49,4105 & 70,3262 & 50,77 & 76,84 \\
\hline
\end{tabular}

Sumber: Data Olahan Penulis, Maret 2016

Berdasarkan hasil pengolahan statistik dengan menggunakan teknik analisis Varian Satu Arah (One Way Anova), dengan menggunakan program SPSS versi 15, seperti yang tertuang pada Tabel 30 pada BAB III halaman 78, maka didapatkan hasil deskripsi tiap sampel dari masing-masing metode peramalan di Hotel EL Cavana Bandung sebagai berikut; (dengan catatan bahwa batas toleransi varian yang diharapkan adalah sebesar $10 \%$, rata-rata aktual tingkat huni kamar di Hotel EL Cavana Bandung adalah sebesar 63,23\%, aktual tingkat huni kamar minimum adalah sebesar 50,9\%, aktual tingkat huni kamar maksimum adalah sebesar 79,4\%, sedangkan rata-rata standar deviasi adalah sebesar 8,92\%, dan rata-rata untuk standar kesalahan (error) adalah sebesar 3,64\%):

1. Deskripsi sampel pertama yaitu Hotel

a. Rata-rata tingkat huni kamar hasil ramalan metode hotel adalah sebesar 75,83\%. Apabila kita bandingkan dengan rata-rata aktual yang terjadi, maka akan didapatkan rata-rata varian sebesar $12,60 \%$. Karena melebihi batas toleransi yang diharapkan, maka rata-rata varian metode hotel dapat dikategorikan "tidak baik." 
b. Standar deviasi metode hotel adalah sebesar 7,53\%. Karena standar deviasinya berada di bawah rata-rata, maka dapat dikategorikan "baik."

c. Standar error metode hotel adalah sebesar 3,07\%. Karena standar errornya berada dibawah rata-rata, maka dapat dikategorikan "baik".

d. Tingkat huni kamar minimum sebesar $70 \%$ dan maksimum adalah sebesar 87,50\%. Apabila kita bandingkan dengan aktual tingkat huni kamar minimum yang terjadi, maka akan didapatkan varian sebesar 19,1\%. Karena melebihi batas toleransi yang diharapkan, maka dapat dikategorikan "tidak baik".. Sedangkan untuk tingkat huni kamar maksimum, didapatkan varian sebesar $8,1 \%$ dengan kategori "baik".

2. Deskripsi sampel kedua yaitu Nä̈ve

a. Rata-rata tingkat huni kamar hasil ramalan metode naive adalah sebesar 60,33\%. Apabila kita bandingkan dengan rata-rata aktual yang terjadi, maka akan didapatkan rata-rata varian sebesar 3,30\%. Karena tidak melebihi batas toleransi yang diharapkan, maka dapat dikategorikan "baik".

b. Standar deviasi metode nä̈ve adalah sebesar 9,80\%. Karena standar deviasinya berada diatas rata-rata, maka dapat dikategorikan "tidak baik".

c. Standar error metode nä̈ve adalah sebesar $4,00 \%$. Karena standar errornya berada diatas rata-rata, maka dapat dikategorikan "tidak baik".

d. Tingkat huni kamar minimum sebesar $50,40 \%$ dan maksimum adalah sebesar 76,70\%. Apabila kita bandingkan dengan aktual tingkat huni kamar minimum yang terjadi, maka akan didapatkan varian sebesar $0,5 \%$. Karena tidak melebihi batas toleransi yang diharapkan, maka dapat dikategorikan —baikll. Sedangkan untuk tingkat huni kamar maksimum, didapatkan varian sebesar 2,7\% dengan kategori "baik".

3. Deskripsi sampel ketiga yaitu Moving Average

a. Rata-rata tingkat huni kamar hasil ramalan metode moving average adalah sebesar 58,92\%. Apabila kita bandingkan dengan rata-rata aktual yang terjadi, maka akan didapatkan rata-rata varian sebesar 4,30\%. Karena tidak melebihi batas toleransi yang diharapkan, maka dapat dikategorikan "baik".

b. Standar deviasi metode moving average adalah sebesar 10,44\%. Karena standar deviasinya berada diatas rata-rata, maka dapat dikategorikan "tidak baik".

c. Standar error metode moving average adalah sebesar 4,26\%. Karena standar errornya berada diatas rata-rata, maka dapat dikategorikan "tidak baik".

d. Tingkat huni kamar minimum sebesar 49,90\% dan maksimum adalah sebesar 76,70\%. Apabila kita bandingkan dengan aktual 
tingkat huni kamar minimum yang terjadi, maka akan didapatkan varian sebesar $1,0 \%$. Karena tidak melebihi batas toleransi yang diharapkan, maka dapat dikategorikan "baik". Sedangkan untuk tingkat huni kamar maksimum, didapatkan varian sebesar 2,7\% dengan kategori "baik".

4. Deskripsi sampel keempat yaitu Exponential Smoothing $(\alpha=0,3)$

a. Rata-rata tingkat huni kamar hasil ramalan metode exponential smoothing $(\alpha=0,3)$ adalah sebesar $70,60 \%$. Apabila kita bandingkan dengan rata-rata aktual yang terjadi, maka akan didapatkan rata-rata varian sebesar 7,37\%. Karena tidak melebihi batas toleransi yang diharapkan, maka dapat dikategorikan "baik".

b. Standar deviasi metode exponential smoothing $(\alpha=0,3)$ adalah sebesar 7,64\%. Karena standar deviasinya berada di bawah rata-rata, maka dapat dikategorikan "baik".

c. Standar error metode exponential smoothing $(\alpha=0,3)$ adalah sebesar $3,12 \%$. Karena standar errornya berada dibawah rata-rata, maka dapat dikategorikan "baik".

d. Tingkat huni kamar minimum sebesar 64,10\% dan maksimum adalah sebesar 82,50\%. Apabila kita bandingkan dengan aktual tingkat huni kamar minimum yang terjadi, maka akan didapatkan varian sebesar 13,2\%. Karena melebihi batas toleransi yang diharapkan, maka dapat dikategorikan "tidak baik". Sedangkan untuk tingkat huni kamar maksimum, didapatkan varian sebesar $3,1 \%$ dengan kategori "baik".

5. Deskripsi sampel kelima yaitu Exponential Smoothing $(\alpha=0,5)$

a. Rata-rata tingkat huni kamar hasil ramalan metode exponential smoothing $(\alpha=0,5)$ adalah sebesar $67,70 \%$. Apabila kita bandingkan dengan rata-rata aktual yang terjadi, maka akan didapatkan rata-rata varian sebesar $4,47 \%$. Karena tidak melebihi batas toleransi yang diharapkan, maka dapat dikategorikan "baik".

b. Standar deviasi metode exponential smoothing $(\alpha=0,5)$ adalah sebesar $8,22 \%$. Karena standar deviasinya berada di bawah rata-rata, maka dapat dikategorikan "baik"

c. Standar error metode exponential smoothing $(\alpha=0,5)$ adalah sebesar $3,35 \%$. Karena standar errornya berada dibawah rata-rata, maka dapat dikategorikan "baik".

d. Tingkat huni kamar minimum sebesar 60,20\% dan maksimum adalah sebesar $80,90 \%$. Apabila kita bandingkan dengan aktual tingkat huni kamar minimum yang terjadi, maka akan didapatkan varian sebesar 9,3\%. Karena tidak melebihi batas toleransi yang diharapkan, maka dapat dikategorikan "baik". Sedangkan untuk tingkat huni kamar maksimum, didapatkan varian sebesar 1,5\% dengan kategori "baik". 
6. Deskripsi sampel keenam yaitu Exponential Smoothing $(\alpha=0,7)$

a. Rata-rata tingkat huni kamar hasil ramalan metode exponential smoothing $(\alpha=0,7)$ adalah sebesar $64,73 \%$. Apabila kita bandingkan dengan rata-rata aktual yang terjadi, maka akan didapatkan rata-rata varian sebesar 2,03\%. Karena tidak melebihi batas toleransi yang diharapkan, maka dapat dikategorikan "baik".

b. Standar deviasi metode exponential smoothing $(\alpha=0,7)$ adalah sebesar $8,81 \%$. Karena standar deviasinya berada di bawah rata-rata, maka dapat dikategorikan "baik".

c. Standar error metode exponential smoothing $(\alpha=0,7)$ adalah sebesar $3,60 \%$. Karena standar errornya berada dibawah rata-rata, maka dapat dikategorikan "baik".

d. Tingkat huni kamar minimum sebesar 56,30\% dan maksimum adalah sebesar 79,20\%. Apabila kita bandingkan dengan aktual tingkat huni kamar minimum yang terjadi, maka akan didapatkan varian sebesar 5,4\%. Karena tidak melebihi batas toleransi yang diharapkan, maka dapat dikategorikan "baik". Sedangkan untuk tingkat huni kamar maksimum, didapatkan varian sebesar 0,2\% dengan kategori "baik".

7. Deskripsi sampel ketujuh yaitu Trend Projections

a. Rata-rata tingkat huni kamar hasil ramalan metode trend projections adalah sebesar 59,87\%. Apabila kita bandingkan dengan rata-rata aktual yang terjadi, maka akan didapatkan rata-rata varian sebesar $3,62 \%$. Karena tidak melebihi batas toleransi yang diharapkan, maka dapat dikategorikan "baik".

b. Standar deviasi metode trend projections adalah sebesar 9,96\%. Karena standar deviasinya berada diatas rata-rata, maka dapat dikategorikan "tidak baik".

c. Standar error metode trend projections adalah sebesar 4,07\%. Karena standar errornya berada diatas rata-rata, maka dapat dikategorikan "tidak baik".

d. Tingkat huni kamar minimum sebesar 50,77\% dan maksimum adalah sebesar 76,84\%. Apabila kita bandingkan dengan aktual tingkat huni kamar minimum yang terjadi, maka akan didapatkan varian sebesar $0,37 \%$. Karena tidak melebihi batas toleransi yang diharapkan, maka dapat dikategorikan "baik". Sedangkan untuk tingkat huni kamar maksimum, didapatkan varian sebesar 2,56\% dengan kategori "baik".

Sedangkan dari perhitungan Anova seperti yang tertuang pada tabel 8, didapatkan hasil bahwa nilai $\mathrm{F}$ untuk keseluruhan metode (Between groupcombined) yakni sebesar 2,97, sedangkan nilai $\mathrm{F}$ untuk linear term-contrast yakni sebesar 2,44, untuk besar nilai F dalam linear term-deviation yakni sebesar 3,08. 
Tourism Scientific Journal

Volume 2 Nomor 1 Desember 2016

Tabel 8. ANOVA-Metode Peramalan Target Tingkat Huni Kamar Hotel EL Cavana Bandung Semester II Tahun 2015

\begin{tabular}{|c|c|c|c|c|c|c|c|}
\hline \multicolumn{8}{|c|}{ Forecast Occupancy } \\
\hline & & & $\begin{array}{l}\text { Sum of } \\
\text { Squares }\end{array}$ & $d f$ & $\begin{array}{c}\text { Mean } \\
\text { Square }\end{array}$ & $\boldsymbol{F}$ & Sig. \\
\hline Between & \multicolumn{2}{|c|}{ (Combined) } & $1.439,568$ & 6 & 239,928 & 2,973 & 0,019 \\
\hline \multirow[t]{4}{*}{ Groups } & \multirow{4}{*}{$\begin{array}{l}\text { Linear } \\
\text { Term }\end{array}$} & Contrast & 196,885 & 1 & 196,885 & 2,440 & 0,127 \\
\hline & & Deviation & $1.242,683$ & 5 & 248,537 & 3,080 & 0,021 \\
\hline & & Within Groups & $2.824,338$ & 35 & 80,695 & & \\
\hline & & Total & $4.263,907$ & 41 & & & \\
\hline
\end{tabular}

Sumber: Data Olahan Penulis, Maret 2016

Dengan menggunakan Post Hoc Test melalui analisis LSD (Least Square Difference), maka kita dapat melihat sejauh mana besar signifikansi antara masing-masing sampel yang ada, seperti yang tertuang pada tabel 32 pada BAB III pada halaman 58. Yang mana dapat disimpulkan bahwa dari masing -masing metode runtut waktu (time series) terhadap penerapan peramalan hotel, metode yang perbedaan rata-ratanya signifikan dengan taraf kepercayaan $95 \%$ atau dengan taraf signifikansi 5\% adalah metode Nä̈ve, Moving Average, Exponential Smoothing dengan $\alpha=0,7$ dan Trend Projection.

Maka pada halaman berikutnya adalah kesimpulan analisa dari tabel Descriptive, Anova dan Post Hoc Test metode peramalan target tingkat huni kamar di Hotel EL Cavana Bandung:

1. Kategori Rata-rata Varian Tingkat Huni Kamar
a. Hotel
: tidak baik
b. Nä̈ve
: baik
c. Moving Average
: baik
d. Exponential Smoothing

$$
\begin{array}{lll}
- & (\alpha=0,3) & \text { : baik } \\
\text { - } & (\alpha=0,5) & \text { : baik } \\
\text { - } & (\alpha=0,7) & \text { : baik* }
\end{array}
$$

e. Trend Projections (Regression) : baik

2. Kategori Standar Deviasi
a. Hotel
: baik
b. Nä̈ve
: tidak baik
c. Moving Average
: tidak baik

d. Exponential Smoothing
- $\quad(\alpha=0,3)$
: baik
- $\quad(\alpha=0,5)$
: baik
- $\quad(\alpha=0,7)$
: baik* 
e. Trend Projections (Regression) : tidak baik

3. Kategori Standar Kesalahan (Error)

a. Hotel

b. Nä̈ve

: baik

c. Moving Average : tidak baik

d. Exponential Smoothing : tidak baik

- $\quad(\alpha=0,3)$

baik

- $\quad(\alpha=0,5)$

: baik

- $\quad(\alpha=0,7)$

: baik*

e. Trend Projections (Regression)

: tidak baik

4. Kategori Varian Tingkat Huni Kamar Minimum
f. Hotel
: tidak baik
g. Nä̈ve
: baik
h. Moving Average
: baik

i. Exponential Smoothing
- $\quad(\alpha=0,3)$
: tidak baik
- $\quad(\alpha=0,5)$
: baik
- $\quad(\alpha=0,7)$
: baik*
j. Trend Projections (Regression) : baik

5. Kategori Varian Tingkat Huni Kamar Maksimum
k. Hotel
: baik
1. Nä̈ve
: baik
m. Moving Average
: baik

n. Exponential Smoothing

$$
\begin{array}{lll}
- & (\alpha=0,3) & \text { : baik } \\
\text { - } & (\alpha=0,5) & \text { : baik } \\
\text { - } & (\alpha=0,7) & \text { : baik* }
\end{array}
$$

o. Trend Projections (Regression) : baik

6. Kategori Perbedaan Rata-Rata (Mean Difference) Metode Hotel terhadap Metode Runtut Waktu (Time Series) dalam Taraf Signifikansi 5\% atau Taraf Interval Kepercayaan $95 \%$.
a. Nä̈ve
: signifikan
b. Moving Average
: signifikan
c. Exponential Smoothing
- $\quad(\alpha=0,3)$
: tidak signifikan
- $\quad(\alpha=0,5)$
: tidak signifikan
- $\quad(\alpha=0,7)$
: signifikan*
d. Trend Projections (Regression) : signifikan 
Apabila kita bandingkan masing-masing metode peramalan berdasarkan keenam kategori diatas, maka metode exponential smoothing dengan $(\alpha=0,7)$ merupakan metode yang paling tepat untuk diterapkan dalam menetapkan target tingkat huni kamar di Hotel EL Cavana Bandung. Hal ini disebabkan karena metode tersebut memenuhi keenam kategori yang telah disebutkan, yakni; "baik" dalam Rata-rata Varian Tingkat Huni Kamar, Standar Deviasi, Standar Kesalahan (Error), Varian Tingkat Huni Kamar Minimum, Varian Tingkat Huni Kamar Maksimum dan "signifikan" dalam Taraf Signifikansi 5\% atau Taraf Interval Kepercayaan 95\% Perbedaan Mean (Mean Difference) Metode Hotel terhadap Metode Runtut Waktu (Time Series).

\section{SIMPULAN}

Berdasarkan pembahasan pada bagian sebelumya, maka dapat ditarik beberapa kesimpulan sebagai berikut:

1. Melalui beberapa tahapan peramalan seperti yang telah dijelaskan penulis dalam bab sebelumnya, penerapan metode peramalan yang dilakukan oleh pihak manajemen yang terkait dalam menentukan target tingkat huni kamar di Hotel EL Cavana Bandung pada semester II tahun 2015 dinilai kurang tepat, hal ini disebabkan karena dalam penetapan target tersebut, pihak manajemen tidak menggunakan metode peramalan yang mana dapat menghasilkan nilai target yang tidak terlalu jauh, dalam arti dapat diterima oleh pihak manajemen yang bersangkutan sesuai dengan fungsi dan tujuan peramalan itu sendiri; dimana hasil peramalan target tingkat huni kamar diharapkan dapat mendekati nilai aktual yang terjadi. Pendekatan secara subjektif melalui jalur diskusi antara Hotel Manager, General Manager, dengan Owner disertai dengan penyesuaian informasi-informasi kualitatif atau bisa disebut sebagai

Owner's Demand with Subjective Analysis Adjustment dinilai tidak dapat memenuhi pencapaian kebutuhan aktual tingkat huni kamar yang diharapkan. Tidak tercapainya target selama beberapa tahun terakhir, dengan memperlihatkan besarnya varian dari aktual terhadap target yang telah ditetapkan sebelumnya dapat menjadi sebuah indikasi akan kurang tepatnya metode yang digunakan pihak manajemen Hotel EL Cavana Bandung dalam menetapkan target tingkat huni kamar selama beberapa tahun terakhir sampai sekarang. Besar rata-rata tingkat huni kamar aktual adalah sebesar 63,23\%. Dengan penetapan yang pihak manajemen Hotel EL Cavana lakukan, besar rata-rata forecastnya yaitu sebesar $75,83 \%$. Maka pencapaian aktualnya hanya sebesar $83,38 \%$. Sedangkan besar rata-rata varian yang dihasilkan dari penetapan target tingkat huni kamar oleh pihak manajemen Hotel EL Cavana Bandung adalah sebesar $12,60 \%$. Dengan menggunakan metode forecast, target rata-rata masing-masing metodenya lebih mendekati nilai aktual yang terjadi, hal ini berarti tingkat pencapaian target masing-masing metode runtut waktupun lebih besar dibandingkan dengan pencapaian target metode yang digunakan hotel, selisih varian yang terjadi pun lebih kecil. Metode peramalan yang baik seharusnya dapat menunjukkan hasil yang paling mendekati nilai aktual yang terjadi maupun yang akan terjadi kedepannya. 
Maka, berdasarkan beberapa pertimbangan seperti yang lebih jelasnya telah tertuang dalam analisis permasalahan pada bab sebelumnya, metode Exponential Smoothing $(\alpha=0,7)$ dapat disimpulkan sebagai metode yang paling tepat karena menghasilkan target rata-rata yang paling mendekati aktual yakni 64,73\%, tingkat pencapaian target sebesar 97,68\%, dengan selisih varian terkecil antara target dan aktual yakni sebesar 2,03\%.

2. Nilai MAPE (Mean Absolute Percentage Error) yang menggambarkan tentang sejauh mana tingkat keakuratan peramalan yang dilakukan oleh pihak manajemen Hotel EL Cavana Bandung dalam menetapkan target tingkat huni kamar pada semester II tahun 2015 adalah sebesar 21,25\%. Dengan nilai tersebut maka penetapan peramalan hotel tersebut berada dalam kategori "tidak baik", karena nilai MAPEnya berada antara 20\% sampai 50\%. "Tidak baik" nya tingkat akurasi peramalan tersebut tentunya akan berpengaruh terhadap besarnya penentuan dan pencapaian target yang diharapkan, dalam hal ini khususnya mengenai tidak tercapainya target tingkat huni kamar di Hotel EL Cavana Bandung. Apabila pihak manajemen dapat menerapkan metode peramalan runtut waktu, yaitu: Nä̈ve, Moving Average, Exponential Smoothing, dan Trend Projection (Regression), maka nilai akurasi atau nilai MAPEnya akan berada dalam kategori yang lebih baik, dengan kata lain akurasi peramalan runtut waktu lebih baik apabila dibandingkan dengan akurasi penetapan pihak manajemen Hotel EL Cavana. Nilai MAPE untuk metode Nä̈ve adalah sebesar 5,18\% ("baik"), metode Moving Average adalah sebesar 6,74\% ("baik"), metode Exponential Smoothing dengan $\alpha=0,3$ adalah sebesar 12,72\% ("kurang baik"), sedangkan metode Exponential Smoothing dengan $\alpha=0,5$ adalah sebesar 7,89\% ("baik"), metode Exponential Smoothing dengan $\alpha=0,7$ adalah sebesar $3,77 \%$ ("baik"),

Sedangkan metode runtut waktu yang terakhir, Trend Projection (Regression) mempunyai nilai MAPE sebesar 5,65\% ("baik"). Dari keempat metode peramalan runtut waktu diatas maka dapat disimpulkan bahwa untuk peramalan target tingkat huni kamar pada semester II tahun 2015, metode peramalan dengan tingkat akurasi terbaik yaitu metode Exponential Smoothing dengan $\alpha=0,7$, karena memiliki nilai MAPE yang terkecil yakni $3,77 \%$.

3. Melalui teknik analisis varian satu arah (One Way Anova), untuk menguji masing-masing metode peramalan runtut waktu termasuk dengan penetapan target yang dilakukan oleh pihak manajemen Hotel EL Cavana Bandung dalam menentukan target tingkat huni kamar pada semester II tahun 2015, dapat disimpulkan bahwa; dengan tabel Descriptives, terdapat enam kategori yang dapat menilai metode mana yang paling tepat untuk diterapkan. Dari hasil keenam kategori tersebut, metode exponential smoothing dengan $\alpha=0,7$ merupakan metode yang paling tepat, karena memenuhi keenam kategori yakni: -baikll dalam Rata-rata Varian Tingkat Huni Kamar, Standar Deviasi, Standar Kesalahan (Error), Varian Tingkat Huni Kamar Minimum, Varian Tingkat Huni Kamar Maksimum, dan — signifikan\| dalam Taraf Sigifikansi 
5\% atau Taraf Interval Kepercayaan 95\% Perbedaan Rata-rata (Mean Difference) Metode Hotel terhadap Metode Runtut Waktu (Time Series). Sedangkan melalui tabel Anova dapat disimpulkan bahwa; terdapat perbedaan yang nyata antara masing-masing metode dengan besar signifikansi 0,019. Dengan hasil nilai $\mathrm{F}$ untuk keseluruhan metode (between group-combined) adalah sebesar 2,97, nilai $\mathrm{F}$ untuk linear term-contrast adalah sebesar 2,44, dan untuk besar nilai F dalam linear term-deviation adalah sebesar 3,08.

Berdasarkan uraian ketiga point diatas, maka dapat disimpulkan bahwa; penerapan metode peramalan runtut waktu (time series) menghasilkan hasil yang lebih baik dibandingkan dengan penetapan target oleh pihak manajemen Hotel EL Cavana Bandung sebelumnya, dan dimana pada akhirnya kesimpulan utama yang dapat penulis utarakan adalah: penerapan metode Exponential Smoothing dengan $\alpha=0,7$ dinilai sebagai metode peramalan yang paling tepat dalam menentukan target tingkat huni kamar di Hotel EL Cavana Bandung pada semester II tahun 2015 .

\section{DAFTAR PUSTAKA}

Chase, Richard B. J, Robert \& Aquilano, N, J. (2006). Operations Management. Eleventh Edition. New York: McGraw Hill International.

Fitzsimmons, J, A. \& Fitzsimmons, M, J. (2006). Service Management. Fifth Edition. New York: McGraw Hill Companies Inc.

Haksever, C,. Render, B. Russell, R, S \& Murdock, R. (2000). Service Management and Operations. Second Edition. New Jersey: Prentice Hall International Inc.

Hanke, H, E. \& Wichern, D, W. (2005). Business Forecasting. Eighth Edition. New Jersey: Prentice Hall.

Heizer, Jay \& Barry, R. (2006). Operations Management. Eighth Edition. New Jersey: Pearson International Edition.

Ismail, A. (1999). Hotel Sales and Operations. Canada: Delmar Publishers.

Kinicki, A, \& Williams, B, K. (2003). Management. New York: McGraw Hill International Edition.

Krajewski, L, J. Ritzman, L, P,. \& Malhorta, M, K. (2007). Operations Management: Processes and Value Chains. Eighth Edition. New Jersey: Pearson International Edition.

Makridakis, S. Wheelwright, S, C. \& Hyndman, R. (1998). Forecasting Methods for Management. New York: John Wiley and Sons Inc. 
Makridakis, S, C. Wheelwright, \& Victor E. M. (1999). Metode dan Aplikasi Peramalan. Jilid satu. Alih Bahasa Sus Andriyanto dan Abdul Basith. Jakarta: Erlangga.

Makridakis, S, C. Wheelwright dan Victor E. M. (2000). Metode dan Aplikasi Peramalan. Jilid dua. Alih Bahasa Ir. Hari Suminto. Jakarta: Erlangga.

Rangkuti, F. (2005). Business Plan. Jakarta: PT. Gramedia Pustaka Utama.

Robbins, S, P. \& Coulter, M. (2004). Manajemen Alih Bahasa. PT. Indeks Kelompok Gramedia

Russell, R,S,. \& Taylor, B, W. (2006). Operations Management. Fifth Edition. New Jersey: John Wiley and Sons Inc.

Setiadi, N, J. (2003). Prakiraan Bisnis. Jakarta: Kencana.

Siswanto, H.B. (2005). Pengantar Manajemen. Jakarta: Bumi Aksara.

Sugiyono. (2005). Metode Penelitian Administratif. Bandung: CV. Alfabeta.

Sulastiyono, A. (2001). Manajemen Penyelenggaraan Hotel. Bandung: CV. Alfabeta

Wagen, L, V. \& Goonetideke, A.( 2004). Hospitality Management: Strategy and Operations. Australia: Pearson Hospitality Press.

Walker, J, R. (2004). Introduction to Hospitality Management. New Jersey: Pearson Prentice Hall.

Williams, C. (2007). Management. Fourth Edition. Oklahoma: Thomson South Western. 